\title{
Technologies Of Use Of People's Oral Creativity In Mother Tongue Classes
}

Rajapova Kumush Masharipovna

Researcher at Karakalpak State University

ANNOTATION: This article discusses the technology of using examples of folklore in native language lessons. There is also information on practical and creative work on proverbs and sayings during the course. There are also ideas about the importance of proverbs and sayings in developing students' speech. The article also focuses on the role of folklore in educating students.

KEYWORDS: stable compound, proverb, proverb, phrase, stable compound, figurative expression, figurative words, synonyms, assimilation, dissimilation, consonance, metathesis, phonetic phenomena.

Article Received: 10 August 2020, Revised: 25 October 2020, Accepted: 18 November 2020

Introduction: The main purpose of the study of mother tongue education is to develop communicative literacy, independent and creative thinking, knowledge of the art of reading and speaking, perfect oral and written skills, spiritually mature person. Because young people can develop into well-rounded, free individuals only if they are properly educated, both physically and spiritually. The main purpose of mother tongue teaching is to know the rules of the language, to use it consciously, to have oral and written speaking skills, to read spelling rules correctly, to think independently, is to cultivate students who are perfect in every way. The main goal required of mother tongue education today is that the child should be able to distinguish every event and every lexical unit, stable connections in the language. He should be able to make extensive use of these linguistic phenomena and lexical units in his oral and written speech. That is, a native language teacher can achieve his or her goal only if the student can use the language in practice. Only then will the child's creative abilities be fully formed and developed. The first step in developing students 'oral and written speech begins with increasing their vocabulary so that only an individual with sufficient vocabulary can express their thoughts correctly using language units appropriately.

Only when a child learns to read and learn his mother tongue will his intelligence, intellect, thinking ability, consciousness and spiritual and moral level increase. In particular, he will be aware of the cultural and historical riches created by the people in the history of the Uzbek people, as well as the achievements of our independent people today. It is a bold step to master the basics of other sciences. That's why a teacher should first and foremost instill in students a love for their mother tongue. Because the love for the mother tongue is closely connected with the love for the Motherland and the people.
From the first days of independence, the Republic began to pay great attention to the national values, culture, spirituality and language culture of our people. As a result, the values and culture of our people, which we have inherited for many years, have been restored. In particular, special attention was paid to the study of unique examples of folklore. In particular, more practical work has been done on the important role of proverbs and sayings in the upbringing of children. Because proverbs and sayings are the conclusions of life, wisdom, spiritual wealth, gems of the people, tested in thousands of years of life. Without studying them, it is impossible to bypass the historical science of ethnography on the origin and ethnic history of peoples, the formation of the peculiarities of their culture and way of life. As we read the text of folk sayings, we believe that our people want their children to be partners, honest, pure, and to rise to the level of brave, patriotic, science-loving people.

Materials and methods. Proverbs and sayings are the most common and characteristic genre of folklore. The history, character, labor activities, and peculiarities of a people's life are as reliable as those imprinted in proverbs or traces of ancient life left on stone.

Folk proverbs and sayings are a concise form of folklore, but a genre with a deep meaning. Such drops of art, each of which demonstrates and is able to demonstrate the beauty of our language, the subtlety of our speech, the intellect and the logic of our thinking with amazing power, are a vivid mirror of our people's centuries-old life experiences and way of life. They fully reflect the attitude of our people to life, nature, man, family and society, socio-political, spiritualenlightenment, moral-aesthetic and philosophical views. That is why proverbs are so widely used and have been used and are being used for centuries in live speech and interpersonal communication, in artistic, historical and scientific works, and in political and journalistic literature. 
Proverbs and sayings are one of the main means of educating the young generation of the Uzbek people, which gained independence today, as well as in the distant past, to the level of a harmoniously developed person, envied by their

Exercise. Read the proverbs. Find and correct misspelled words. Use a spelling dictionary where difficult.

Ilim o 'lchovi-aqil,

Zehin o'lchovi-naql.

Kitop ko 'rmagan kala-

Giyox unmagan dalla.

Bilmaganini so 'rap organgan olim,

Orlanip suramagan o'ziga zolim.

During this exercise, students identify the following words that are misspelled in the essay: science, reason, mind, book, kala, giyohdalla, sorap, orlanip. These are the words that help you

Exercise. Give the rest of the sentences and explain how the highlighted letters differ from the others.

Ish ishtaha ochar ...

Mehnat.Mehnatning tagi ...

Uchish ga qanot kerak,

O'qishga... ancestors. Proverbs and sayings can be used effectively in the teaching of all areas of linguistics. For example, in phonetics classes, especially in the 5 th grade textbook "Mother Tongue", the following exercises are given:

The measure of knowledge is the mind,

The measure of mind is transference.

Bookworm

A field without herbs.

The scientist who asked what he didn't know,

He is cruel to himself.

identify the mistakes and replace them with the correct ones. Exercises like the ones above make students think and increase their ingenuity. It also helps to develop oral and written communication.

Business appetite...

Labor.Labor tag ning

You need wings to fly,

To read...

Exercise. Write the text below, stating which consonant letters are formed in the pronunciation.

XI asrda yashagan bobomiz Mahmud In the work of our 11th century ancestor Mahmud Koshg'ariyning "Devonu lug'otit turk" asarida Kashgari "Devonulug'otitturk" "The lips of the diligent "Tirishqoqning labi yog'liq - erinchoqning boshi are fat - the head of the lazy is bloody", There are qonlik", "Yoshlikda tirishib harakat qilgan odam, katta bo'lgach sevinadi", "Baxt belgisi ilmdir", many folk proverbs such as

"Odobning boshi til” kabi ko "plab xalq maqollari o'rin olgan.

Such exercises are widely covered in the textbook "Modern Uzbek literary language" of academic lyceums. A number of exercises can be cited as examples of this.

The textbook "Modern Uzbek Literary Language" for the first group contains a lot of exercises: For example, at the beginning of the textbook we will focus on Exercise 12 for the topic of general repetition:

Exercise. Read and memorize proverbs. Divide the words into categories.

Mehnat - hayot tomiridagi qon.

Bugungi mehnat - ertaning rohati.

Mehnatni hurmatlasak, u bizni e'zozlaydi.

Inson mehnat bilan ulug 'lanadi.

Baxtning kaliti mehnatning cho 'ntagida.

Bog'-u bo'stonlar - mehnat mahsuli.

Gul uzishdan oldin gulzor yaratadilar.

Mehnatkash odam fisq-fasod gaplarni bilmaydi.

Mehnat odamni hayot qiyinchiliklaridan qutqaradi.

Yalqovlik bor yerda ko'z bo 'yash bor.

Yumshoq paxta qattiq mehnatning mahsulidir.

Mashaqqatning mahsuli farog 'atdir.

Odam mehnatini yoysa, mehnati uning shuhratini yoyadi.

Odam bahosizdir, ammo uni mehnati baholaydi.

Mehnat - yo 'qchilikningkushandasi.
Labor is the blood in the veins of life.

Today's work is tomorrow's pleasure.

If we respect work, it will respect us.

Man is honored by his work.

The key to happiness is in the pocket of work.

Gardens and orchards are the product of labor.

Before flowering, they create a flowerbed.

The industrious man does not know corruption.

Work saves a person from the hardships of life.

Where there is laziness, there is tears.

Soft cotton is the product of hard labor.

The fruit of hardship is rest.

When a man spreads his labor, his labor spreads his fame.

Man is priceless, but he is valued by his labor.

Labor is a relative of poverty.

All the phrases in our language are included in the folk sayings in this exercise. Students group these phrases and explain the meaning of each sentence. Additionally, you may be asked to memorize these proverbs as a homework assignment. 
The following exercises relate to Lesson 17, Assimilation, Dissimilation, Silence, Metathesis, and Other Phonetic Phenomena, for this group:

Exercise. Read the following text according to the rules of orthoepy, follow the pronunciation of words.

Oltin o'tda bilinadi, odam - mehnatda. Mehnat bilan inoqlashsang, tan og'rig'in ko'rmassan. Ko'p ishlovchi ko 'p yashaydi. Mehnat qilsang, ko 'nglingga yorug 'lik tushadi. Odamlar sening chiroyingga, kiygan kiyimingga qarab emas, balki qilgan ishingga qarab turib baho beradilar. Yashash uchun foydali mehnat qilish kerakligini anglab yetish insonlikning birinchi shartidir.

Dangasavayalqovlarhechqachonsanoqdabo 'lmaydi.
Gold is known in fire, man is in labor. When you make a serious effort, you can achieve the extremely fast. Many who work live long. When you work hard, you feel enlightened. People judge you by what you do, not by the beauty you wear. Realizing that one has to do useful work in order to survive is the first condition of humanity. Lazy and lazy people are never counted.
When we use proverbs in the classroom, we should pay special attention to their educational value. The following exercise contains a number of profound and fraternal proverbs:

\section{Exercise. Read proverbs expressively. Identify phonetic phenomena in words.}

\begin{abstract}
dushman yaxshi.
Mehnathayotchirog 'igayog ‘

oldinda turgan

(Gruzinmaqoli) quyadi,

tafakkuresauniyoritadi. (Inglizmaqoli) Nodonaytur: g'olibchiqdim, donoaytur: yo'lberdim. (Tatar maqoli) Dono olg'a boraturib, orqaga qarab qo'yadi. (Pushtun maqoli) Aqlli xalqqa intilsa, nodon $o$ ' $z$ qarindosh-urug'lariga intiladi. (Qirg'iz maqoli) Ozodlik — obodlik. (Tojik maqoli) Do'stlik shishaga monand, sinsa - ulay olmaysan. (Rus maqoli) Kishilarga muhabbat - eng yaxshi davlat. (Arab maqoli) Yakkani bo 'ri yer. (Qoraqalpoq maqoli)
\end{abstract}

Results and discussions. By doing the above exercises, students will learn the rules of spelling, as well as increase their interest in the literature and folklore of other nations. The main purpose of these exercises is to enrich the spiritual world of students.

Teaching proverbs and sayings in this order will increase students' vocabulary. The variety and appeal of the speech is ensured. In short, students' speaking skills will improve.

The teacher's skill is evident in his effective use of proverbs throughout the lesson. Students like proverbs, so they do their homework with proverbs. With this in mind, the teacher uses a variety of exercises related to proverbs and parables to teach students the metaphorical meaning of words, the expression of multiple meanings.

Conclusion. Thus, the rare examples of folklore play an important role in enriching the speech of students and bringing them up in a comprehensively developed and mature way. Samples of folklore are very useful for reading, conversation, storytelling, grammar analysis and writing. They are compact, meaningful and effective; develops students' artistic taste, teaches them to think logically, to look at speech attentively, plays an important role in aesthetic education. Textbooks provide examples of folklore
Better a poor horse than no horse at all. (Georgian proverb) Work adds fuel to the light of life, and thought illuminates it. (English proverb) The fool says: I have won, the wise says: I have given. (Tatar proverb) The wise man goes forward and looks back. (Pashtun proverb) When a wise man strives for the people, the fool strives for his relatives. (Kyrgyz proverb) Freedom is prosperity. (Tajik proverb) Friendship is like a bottle, you can't connect it. (Russian proverb) Love for people is the best state. (Arabic proverb) A lone wolf eats. (Karakalpak proverb)

from a variety of topics in the exercise texts, depending on the topic. Students read them and connect the read work with the moral problem, with the living conditions. Therefore, these immortal treasures of folklore are a great help in educating students to be resourceful and intelligent, as well as to cultivate them morally.

\section{References:}

1. Karimov.I.A. High spirituality is an invincible force. - T., 2008.

2. Mahmudov N., Nurmonov A., Sobirov A., Kadyrov V. Mother tongue. Textbook for 5 th grade of general secondary schools - $\mathrm{T}$ : Manaviyat, 2017.

3. A.Nurmanov, A.Sabirov, N.Qosimova. "Modern Uzbek literary language"For academic lyceums and professional colleges. Tashkent«Ilmziyo»-2011.

4. Gulomov A. Kobilova B. Speech training. Methodical manual "Teacher", Tashkent 1995.

5. Nematov H., Gulomov A., Ziyodova T. Improving students' vocabulary. Teacher's Guide. $\mathrm{T} .:$ Teacher, 1996.

6. Saidov M. Learning tasks and methods of using them in the process of teaching the native language in the 5th grade of Uzbek schools: ped. fan. nom-di diss. avtoref.TDPU. -T.2000. 
7. Pirnazarov, N. (2020). Philosophical analysis of the issue of spirituality. International Journal of Advanced Science and Technology, 29(5), 1630-1632.

8. Berdimuratova, A. K., \& Mukhammadiyarova, A. J. (2020). Philosophical and methodological aspects of the interaction of natural environment and man. InternationalJournalofPharmaceuticalResear ch, 12(3), 1722-1727. doi:10.31838/ijpr/2020.12.03.235

9. Elizaveta, K., Govkherjan, Y., \& Abdurashidovha, M. F. (2020). The problem of good and evil in the world according to the philosophical teachings of avecinna. International Journal of Advanced Science and Technology, 29(5), 2415-2428.

10. Pirnazarov, N. R. ulı. (2020). INFLUENCE OF VIRTUAL REALITY ON THE SPIRITUALITY OF INFORMATION SOCIETY. EurasianUnionScientists. https://doi.org/10.31618/esu.24139335.2020.2.71.587

11. Berdimuratova A, «Tileubergen Jumamuratov shıǵarmashılıǵ1 filosofiyalıq analizdiń ob'ekti retinde», Adam álemi 3 (85) 2020, 19-28

12. KurmanovAibekPuharbaevich, IbragimovBayniyazAytbaevich.
Psychological-pedagogical features of studying enterprise (entrepreneurship education in the system of public education). PalArch's Journal of Archaeology of Egypt / Egyptology, 17(7), 1294712950. Retrieved from https://archives.palarch.nl/index.php/jae/article/vie w/4975

13. Kerimbergenovich, A. A., Kamilovich, S. S., Tursinbaevich, A. R., Jannazarovich, A. K., Kazievich, S. J., \&Maksetovich, O. H. (2020). Ecotourism development in the republic of Karakalpakstan: Historical places and protected areas. JournalofCriticalReviews. https://doi.org/10.31838/jcr.07.12.220

14. Kerimbergenovich, A. A., Kamilovich, S. S., Tursinbaevich, A. R., Jannazarovich, A. K., Kazievich, S. J., \&Maksetovich, O. H. (2020). Ecotourism development in the republic of Karakalpakstan: Historical places and protected areas. Journal of Critical Reviews. https://doi.org/10.31838/jcr.07.12.220

15. Zumrad, U., \&Alimov, A. (2020). Problems of the Development of Tourism and Recreational Services in Uzbekistan in the Context of a Global Pandemic. InternationalJournalofFutureGenerationCommunic ationandNetworking. 